\title{
Proliferation of Transnational Labour Standards: The Role of the ILO
}

\author{
Yifeng Chen
}

\section{Contents}

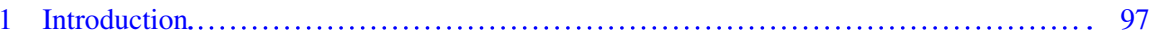

2 Coining Fundamental Labour Rights: Inventing a Managerial Vocabulary............... 98

3 The Proliferation of Labour Standards: The Rise of Transnationalism................ 102

4 In Relation to ILO Standards: The Ambivalence of Transnational Labour Standards. ... 108

5 Institutional Politics of Labour Standards......................................... 111

6 The Future of the ILO: Leadership in Intellectuality and Normativity................ 114

References.................................................................. 117

\section{Introduction}

What marks the international labour protection of the past two decades has been the upsurge of transnational labour standards outside the formal scheme of the ILO. Labour standards are increasingly to be found in free trade agreements, investment arrangements, policy documents of international financial institutions (IFIs), and social missions of multinational corporations. Recognizably, a growing body of labour standards has been nested into transnational settings such as the human rights regimes, trade or investment agreements, development finance, or corporate social responsibility. ${ }^{1}$ The promotion of labour standards has suddenly become a fashionable cause to pursue. Like it or not, mushrooming transnational labour standards leads to fragmentation, conflicts and competition, both normative and institutional.

While remaining the intellectual centre and normative champion for international labour protection, the ILO no longer enjoys a monopolistic position. As the leading institution in setting and promoting international labour standards, the ILO with its law-making activities has been long appreciated by states, trade unions and other international organizations. However, the making of labour standards has become decentralized. The ILO itself has slowed down its pace of producing

${ }^{1}$ See generally Hepple (2005) and Craig and Lynk (2006).

\footnotetext{
Y. Chen $(\bowtie)$

Peking University Law School, Beijing, China

e-mail: yifeng.chen@pku.edu.cn
} 
international labour conventions in recent years. This is in sharp contrast to the proliferation of labour standards outside the ILO. Along with the diffusion of transnational labour standards comes the issue of fragmentation of normativity. The ILO's standards, however authoritative, are not necessarily superior to those formulated in transnational settings. This is aptly described as "competition between mandates and objectives". ${ }^{2}$

In the post-national constellation, labour protection has been mainstreamed as a powerful language for governance and distribution, and international actors have strategically presented themselves as actors of labour governance. The enactment and enforcement of those transnational labour standards are largely self-standing. They are useful supplements, as well as strong competitors, to the international labour conventions and to the existing ILO supervisory mechanisms. They open new paths of global labour governance. These new developments have led to the emergence of transnational labour law as a pertinent field of research. ${ }^{3}$

This chapter examines the possible role of the ILO in the face of fragmentation of labour standards. It starts with a historical account of the institutional transformation of the ILO in the aftermath of the Cold War. Section 2 highlights how the proclamation of fundamental labour rights has equipped the ILO with a managerial vocabulary. Then Sect. 3 traces the trajectory of the diffusion of labour standards in transnational settings, notably in trade agreements and international financial policies. Section 4 examines the relationship between transnational labour standards and ILO standards against a background of institutional competition between regulatory authorities. Section 5 further examines how the fragmentation of labour standards may lead to the institutional politics of substantive labour standards. Section 6 concludes with some critical reflection on the possible strategies the ILO might employ to promote greater consistency and coherence of labour standards in globalization.

\section{Coining Fundamental Labour Rights: Inventing a Managerial Vocabulary}

The ILO had experienced a bitter institutional transformation in a quest for relevance in the post-Cold War world order. ${ }^{4}$ Internally, the usefulness of the ILO was put into question by its Western members as well as the employers' group. Once conceived as an institution of anti-communism, ${ }^{5}$ with the collapse of the former

\footnotetext{
${ }^{2}$ Maupain (2013), p. 18.

${ }^{3}$ See, for example, Blackett and Trebilcock (2015).

${ }^{4}$ Michel Hansenne, who served as Director-General of the ILO from 1989 to 1999, in his several reports to the international labour conference, openly reflected upon various challenges the organization was facing in the post-Cold War era. See, for example, ILO (1994).

${ }^{5}$ This opinion is unambiguously testified by J. Ernest Wilkins, then the Assistant Secretary of Labor for International Labor Affairs with the Eisenhower administration before the Senate of the
} 
Soviet Union the ILO was suddenly seen as being "costly and archaic", and "illsuited to an era in which the role of labor unions is vastly diminished". ${ }^{6}$ The employers' group turned hostile towards the making of international labour standards as well as the operation of ILO supervisory mechanisms. ${ }^{7}$ Internationally, the policymaking of economic and financial institutions, taking structural adjustment as an example, was observed to have a larger bearing than the ILO on the conditions of workers. ${ }^{8}$ The ILO was simply side-lined in the regulatory vocation of economic globalization. ${ }^{9}$ It is useful to recall an internal observation by an ILO official in 1994 that the ILO was facing the challenges of "competing organizations", "competing standards", and ultimately, "competing visions". ${ }^{10}$

Ironically, it was the unresolvable labour/trade debates that reinstated the ILO to the forefront of international policy-making in the mid-1990s. The proposal by the United States at the Uruguay Round to include "internationally recognized labour rights" 11 was strongly resisted by developing countries. Yet the labour/ trade debates continued both within and outside the newly established WTO. While the Marrakesh Agreement of 1994 did not include a labour clause, the North American Agreement on Labor Cooperation came into effect on 1 January 1994 as a side deal to the North American Free Trade Agreement. An 1995 OECD study on core workers' rights and international trade suggested that the negative impact of labour rights enforcement on economic competitiveness was unfounded. ${ }^{12} \mathrm{At}$ the same time, Asian-Pacific countries and developing countries were increasingly concerned over the possibility of labour standards being used for trade protectionist purposes. This led to the decision at the Singapore Ministerial Conference in 1996 to relocate the labour issue back to the ILO. In pronouncing their commitment to "internationally recognized core labour standards", the WTO members expressly acknowledged the ILO as being "the competent body to set and deal with these standards". ${ }^{13}$

United States in 1957. See United States Senate (1957), p. 19.

${ }^{6}$ Quoted from a letter by Jesse Helms, Chairman of the US Senate Foreign Relations Committee sent to Pete V. Domenici, Chairman of the US Senate Budget Committee, dated 26 April 1995. The letter is reproduced in United States Senate (1995), pp. 333-338.

${ }^{7}$ The crisis of tripartism with the ILO continues to this day. See La Hovary (2018).

${ }^{8}$ The ILO tried to initiate institutional dialogue with the World Bank and the IMF as early as the late 1980s. As part of its efforts, the ILO, in cooperation with other parts of the UN system and the Bretton Woods institutions, organized a High-level Meeting on Employment and Structural Adjustment in November 1987, yielding no concrete result.

${ }^{9}$ See ILO (1994), pp. 16-17.

${ }^{10}$ Swepston (1994).

${ }^{11}$ GATT (1987).

${ }^{12}$ OECD (1996).

${ }^{13}$ WTO (1996) Singapore Ministerial Declaration adopted on 13 December 1996, Ministerial Conference, Singapore, 9-13 December 1996. Available at: https://www.wto.org/english/thewto_e/ minist_e/min96_e/wtodec_e.htm. Accessed 6 May 2020. 
The ILO itself worked proactively to revitalize its institutional role in the face of globalization. As early as June 1994, the Governing Body of the ILO set up the Working Party on the Social Dimensions of the Liberalization of International Trade. ${ }^{14}$ The ILO vigilantly followed the involvement of other international organizations in labour issues. In collaborating with the Secretariat of the United Nations, the ILO was substantially involved in preparation for the 1995 World Summit for Social Development. The Copenhagen Declaration and Programme of Action not only affirmed the leading role of the ILO in labour standards, but also for the first time in history formally pronounced the term "basic rights of workers". ${ }^{15}$ From the perspective of the ILO, the 1995 World Summit and the 1996 WTO Declaration imbued the ILO with a renewed sense of political meaning and relevance. Seeing the call as an historic opportunity, the then Director-General Michel Hansenne in his 1997 report to the International Labour Conference immediately proposed that the ILO should adopt a declaration pronouncing a list of fundamental labour rights, be selective and strategic in standard-setting, and, most importantly, set the "social rules of the game of globalization". ${ }^{16}$

In 1998 the International Labour Conference had before it the agenda of adopting a declaration on fundamental labour rights. Yet the clash of governmental positions continued from the WTO to the ILO. A Committee on the Declaration of Principles was established by the Conference to reconcile the differences among different groups. The industrialized market economy countries were the active proponents of the declaration. It was asserted that fundamental labour rights were "universal, not relative", "absolute, not conditional", while their promotion constituted "a universal commitment irrespective of the economic, social or cultural conditions of any member State". ${ }^{17}$ Moreover, enforcement of those labour standards would not rule out the possibility of recourse to trade measures in addition to the ILO's existing mechanisms. ${ }^{18}$ This position was strongly countered by the Asia Pacific Group as well as many developing countries. They were deeply concerned that the WTO might incorporate labour standards and therefore highlighted the ILO as being "the sole competent international organization mandated to set and deal with labour standards". The measures to realize fundamental labour rights should be strictly "promotional and not complaints-based", and not introduce "unilateral or multilateral trade measures". ${ }^{19}$

After lengthy debate, the Declaration on Fundamental Principles and Rights at Work was adopted by the International Labour Conference on 18 June 1998. The Declaration embodies, for the first time in the ILO's history, a set of labour rights

\footnotetext{
${ }^{14}$ See ILO (1994) Governing Body Working Party on the Social Dimensions of the Liberalization of World Trade (GB.261/WP/SLD/1), Governing Body, 261st Session, Geneva, 1994. 
characterized by fundamentals, i.e., freedom of association and collective bargaining, prohibition of forced labour, prohibition of child labour, and non-discrimination in respect of employment and occupation. ${ }^{20}$ Moreover, the Declaration highlights the universality of fundamental labour rights as they emanate from the ILO constitution. States "have an obligation, arising from the very fact of membership in the Organization, to respect, to promote and to realize" those fundamental principles and rights. It was to the satisfaction of developing countries that the Declaration also states that "labour standards should not be used for protectionist trade purposes".

The Declaration is a self-proclamation of the ILO's constitutional authority on labour regulation in the division of labour among international organizations. By incarnating a set of fundamental labour rights the ILO had successfully reinvigorated its international foothold in globalization. ${ }^{21}$ The concept of fundamental labour rights is not primarily addressed to member states, as the Declaration-being "a political statement of a non-binding nature"- does not establish new obligations on ILO members. The genuine audience for the 1998 Declaration, actual or potential, goes beyond ILO constituents, but would reach all relevant international actors such as international trade or financial institutions. The Declaration has enabled the ILO to associate itself with a set of managerial vocabulary, and to have a fair share in regulatory competition in deepening globalization. In this sense, the Declaration is indeed a step towards revitalization, not retreat. ${ }^{22}$

The adoption of the 1998 Declaration also marks a profound institutional transformation of the ILO. ${ }^{23}$ Since then, the ILO has reformed its traditional approach to international labour standard-setting. The ILO is no longer obsessed with making hard international labour conventions. The number of labour conventions produced by the ILO has steadily declined over the past two decades. The ILO also increasingly uses declarations, recommendations and other soft documents for its normative activities. In addition to setting standards for states, the ILO increasingly addresses international organizations, social partners and others. The ILO does not only provide the forum for states to debate and formulate labour standards, but has also turned itself into a developmental organization to promote labour standards. ${ }^{24} \mathrm{The}$

\footnotetext{
${ }^{20}$ The core labour rights enshrined in the Declaration are embodied in and endorsed by eight ILO fundamental conventions, chronologically, the Forced Labour Convention, adopted 28 June 1930 (No. 29); the Freedom of Association and Protection of the Right to Organize Convention, adopted 9 July 1948 (No. 87); the Right to Organize and Collective Bargaining Convention, adopted 1 July 1949 (No. 98); the Equal Remuneration Convention, adopted 29 June 1951 (No. 100); the Abolition of Forced Labour Convention, adopted 25 June 1957 (No. 105); the Discrimination (Employment and Occupation) Convention, adopted 25 June 1958 (No. 111); the Minimum Age Convention, adopted 26 June 1973 (No. 138); and the Worst Forms of Child Labour Convention, adopted 17 June 1999 (No. 182).

${ }^{21}$ See de Wet (2010).

${ }^{22}$ See Maupain (2005).

${ }^{23}$ For a useful account of the origin, history and reality of the 1998 Declaration from an insider's perspective, see Tapiola (2018).

${ }^{24}$ See Standing (2008).
} 
ILO has transformed from a relatively closed inter-state institution to a dynamic global actor.

With the adoption of the 1998 Declaration and its follow-up, the ILO embarked upon fundamental labour rights advocacy. This includes two strategies. One front is the campaign with the member states for universal ratification of ILO fundamental labour conventions, a recognizable success if measured by the growth in the number of treaty ratifications. On the other front, the ILO has initiated dialogues on the possible integration of labour standards with international organizations whose work may have significant labour ramifications, including international financial institutions. A growing international recognition of fundamental labour rights was observed as of the beginning of the new millennium.

Since then, the leading role of the ILO in labour issues receives broad recognition from other international organizations. In 2008 the ILO further adopted its Declaration on Social Justice for a Fair Globalization, asserting the ILO's “responsibility to examine and consider all international economic and financial policies in the light of the fundamental objective of social justice". ${ }^{25}$ Inter-agency cooperation between the ILO and international financial institutions, despite their continued differences in terms of approaches to labour, was further deepened after the 2008 economic crisis. ${ }^{26}$

\section{The Proliferation of Labour Standards: The Rise of Transnationalism}

As the ILO endeavoured to reinvigorate its role in international labour regulation, an observable trend has been the global diffusion of labour standards in transnational settings. Indeed, the recognition and enforcement of labour standards in transnational settings can hardly find its role in the traditional procedures of ILO standardsetting practice. The process started with the signing of the North American Agreement on Labor Cooperation by Canada, the United States, and Mexico on 14 September $1993 .{ }^{27}$ While the level of protection defers largely to national labour law and cooperation was provided for exchanges of information, technical assistance and consultations, the Agreement nevertheless established a dispute settlement procedure for dealing with "persistent patterns of failure" to effectively enforce technical labour standards on occupational safety and health, child labour and minimum

\footnotetext{
${ }^{25}$ ILO, Declaration on Social Justice for a Fair Globalization. Adopted by the International Labour Conference, 97th Session, Geneva, 10 June 2008.

${ }^{26}$ The Summit of G20 at London in April 2009 requested the ILO to assess the labour impact of the actions taken and advise on further measures. See G20 Leaders' Statement, The Global Plan for Recovery and Reform, 2 April 2009. Available at: https://www.treasury.gov/resource-center/international/g7-g20/Documents/London\%20April\%202009\%20Leaders\%20final-communique.pdf. Accessed 6 May 2020.

${ }^{27}$ For an early account, see Compa (1995).
} 
wage. ${ }^{28}$ Backed by the possibility of trade sanctions, a third-party mechanism as such was not only progressive and innovative, but also seen by many as aggressive and intrusive.

The second treaty of the United States that referred to labour waited until its free trade agreement (FTA) with Jordan in 2000. The labour chapter of this FTA is succinct. It made express reference to the commitment of the parties to the 1998 ILO Declaration. In terms of substantive protection, it covers "internationally recognized labor rights" and parties are under a specific obligation not to "encourage trade by relaxing domestic labor laws". ${ }^{29}$ As the US Trade Act of 2002 requires the government to pursue promotion and enforcement of international labour rights, almost all subsequent FTAs concluded by the United States incorporate a labour chapter. Examples include the United States-Singapore Free Trade Agreement of 2003, the United States-Central America Free Trade Agreement of 2004, and a number of others. The most ambitious labour chapter was probably the Trans-Pacific Partnership Agreement of 2016 under the Obama administration, ${ }^{30}$ although the signature of the United States was shortly withdrawn with the change of administration.

Since 2008, states have been more receptive towards the inclusion of a labour provision in FTAs. The number of FTAs with a labour provision has grown rapidly. According to the ILO, by 2016 there were "a total of 77 trade agreements with labour provisions, involving 136 economies". ${ }^{31}$ Notably the United States, Canada, and the European Union have been the most active promoters in this regard. It is also observed by the ILO that the majority of labour provisions are to be found in agreements between developed and developing countries, accounting for $70.1 \%$ of the total number of FTAs with a labour provision. ${ }^{32}$ Yet most FTAs on labour relates to information, cooperation and technical assistance. The application of dispute settlement procedure to the enforcement of labour standards is still rare, and often only if and to the extent that violation of labour standards has directly affected trade between the parties. ${ }^{33}$

Outside trade agreements, a parallel development has been the changing attitude of IFIs and their growing engagement with labour protection. The incorporation of labour protection into the work of IFIs has been a fairly recent phenomenon. The change of position is largely a response to growing external pressure wrought on

\footnotetext{
${ }^{28}$ Canada-Mexico-United States: North American Agreement on Labor Cooperation. In: American Society of International Law (1993) International Legal Materials 32(6): 1499-1518.

${ }^{29}$ United States (U.S.)-Jordan: Agreement Between The United States of America and the Hashemite Kingdom of Jordan on the Establishment of a Free Trade Area. In: American Society of International Law (2002) International Legal Materials 41(1): pp. 63-85.

${ }^{30}$ Trans-Pacific Partnership Agreement, 4 February 2016.

${ }^{31}$ International Labour Office (2016) Third Item on the Agenda - labour-related provisions in trade agreements: recent trends and relevance to the ILO (GB.328/POL/3), Governing Body, 328th Session, Geneva, 27 October-10 November 2016.

${ }^{32}$ ILO (2017), p. 12.

${ }^{33}$ See Bolle (2016).
} 
IFIs. The neo-liberal prescriptions of IFIs met with doubts from borrowing countries and were increasingly challenged among scholars in 2000s. Pressure from the trade unions in large shareholders, such as the American Federation of Labor and Congress of Industrial Organization (AFL-CIO), ${ }^{34}$ also plays an influential role in pressing for the policy changes of the World Bank and the International Monetary Fund (IMF).

Labour protection started to enter into the work of IFIs only after the 2000s. This was pioneered by a modest reference to core labour standards in the social protection strategy of the Asian Development Bank (ADB) in 2001. The ADB committed to ensuring that its procurement of goods and services, contractors, subcontractors and consultants would be in compliance with core labour standards. ${ }^{35}$ Full recognition of labour standards had to wait until the adoption of Performance Standards on Social and Environmental Sustainability by the International Finance Corporation (IFC) in 2006. ${ }^{36}$ Labour and working conditions are featured as a self-standing performance standard under the IFC. This was the first time a significant IFI had given its full endorsement to labour standards in an operational policy.

The successful incorporation of labour standards by the IFC is largely attributable to the fact that the IFC engages exclusively in private sectors. Those potential clients who gain access to the IFC are usually economically better-off, administratively well-organized companies. These IFC policy requirements are often in alignment with existing corporate policies on social responsibility and their implementation does not raise insurmountable difficulties from the perspective of a company. Moreover, in essence, the labour policy of the IFC usually goes little beyond requiring companies to comply with existing national laws where they operate. The scenario would get much more complicated if an IFI which engages principally in public lending tries to extend its policy to labour issues.

The example set by the IFC was quickly followed by the European Bank for Reconstruction and Development (EBRD) in 2008. ${ }^{37}$ The EBRD adopted its first environmental policy in $1991 .{ }^{38}$ A renewed version of the Environmental and Social Policy was adopted in 2008, with labour and working conditions inserted as a separate standard. ${ }^{39}$ The EBRD acknowledges its due diligence obligation not to finance projects in contravention of the host country's international legal obligations on environmental protection and human rights. At the same time, the European Investment Bank (EIB) in 2009 adopted Environmental and Social Principles and

\footnotetext{
${ }^{34}$ The AFL-CIO has repeatedly requested the World Bank and IMF to commit to international labour standards. See, for example, AFL-CIO (1998); AFL-CIO (2000).

${ }^{35} \mathrm{ADB}$ (2003), pp. 15-16.

${ }^{36}$ IFC (2006).

${ }^{37}$ The EBRD expressly acknowledged that its policy review is partly driven by the adoption of performance standards by the IFC in 2006. See EBRD (2008a), p. 42.

${ }^{38}$ It is to be noticed that in the previous version of the Environmental Policy of 2003, the EBRD had already addressed "worker protection issues" including occupational health and safety, harmful child labour, forced labour and discriminatory practices. See EBRD (2003).
}

${ }^{39} \mathrm{EBRD}$ (2008b). 
Standards and expressly acknowledged ILO core labour standards. ${ }^{40}$ The EIB policy applies to both public and private sectors, albeit the ensuing obligations of clients in different sectors do differ in nature. ${ }^{41}$

The precedents set by the IFC, the EBRD and the EIB were inspiring and encouraged other IFIs. Since then, there has been a growing acceptance of labour standards among IFIs. Of course, a number of IFIs have refrained from instituting a labour policy so far - the IMF and the International Fund for Agricultural Development (IFAD) being prominent examples. As for those IFIs that incorporate labour standards, there are roughly two categories. In some cases, a comprehensive framework for labour protection has been pursued. For example, in 2013 the African Development Bank (AfDB) Group ${ }^{42}$ adopted its Integrated Safeguards System. ${ }^{43}$ Its policy on labour protection is also comprehensive and is close to that of the IFC and of the EBRD. Another high profile case was the adoption by the World Bank of its Environmental and Social Framework in 2016 after several years of consultation and debates. In those cases, labour protection is established as a highly elaborate, substantive, and self-standing standard.

In some other cases, a succinct version of an environmental and social policy is enacted with a brief reference to labour standards. An example here might be the Sustainability Policy of the Nordic Investment Bank (NIB) adopted on 1 September 2011, with the NIB requiring its clients to respect the four core labour rights and to provide safe and healthy working conditions. ${ }^{44}$ The Black Sea Trade and Development Bank (BSTDB) also upgraded its Environmental and Social Policy in 2013 and openly committed to "respect for human rights in a working environment", as embodied in ILO core labour standards. ${ }^{45}$ In 2016 the New Development Bank (NDB) adopted its Environmental and Social Framework which sets occupational health and safety at the centre of labour protection. ${ }^{46}$ And in the same year, the Asian Infrastructure Investment Bank (AIIB) approved its Environmental and Social Framework and prescribed labour standards for both public and private sectors. In addition, projects involving use of forced labour or child labour are expressly listed on the AIIB's list of exclusions from financing. ${ }^{47}$

It is safe to summarize that the development of international labour protection during recent decades is characterized by the proliferation of labour standards in transnational settings. The body of transnational labour standards is not monolithic, but rather amorphous. It is not a single set of uniform labour standards, but an

\footnotetext{
${ }^{40}$ EIB (2013), pp. 18-19.

${ }^{41}$ Ibid, p. 15.

${ }^{42}$ The African Development Bank Group includes the African Development Bank (AfDB) and African Development Fund (AfDF).

${ }^{43}$ African Development Bank Group (2013).

${ }^{44}$ NIB (2012).

${ }^{45}$ See BSTDB (2014).

${ }^{46}$ NDB (2016).

${ }^{47}$ AIIB (2016).
} 
aggregation of various sets of independent labour standards practised in transnational settings. To group all those standards under the label of transnational labour standards risks reduction and oversimplification of the richness, diversity and nuances of labour standards in transnational settings. Yet, they share the sentiment that labour standards may grow and develop outside the ILO conventions, and may not rely on the ILO for their implementation.

One should not overlook the heterogeneity and richness of those transnational labour standards. Yet, some core elements may be observed. Firstly, the ILO conventions and standards, prominently the 1998 Declaration, have been the centrepiece of the normative project of transnational labour standards. Most of them have made express reference to the 1998 Declaration. ${ }^{48}$ In most cases, all four categories of fundamental labour rights are acknowledged. Yet, it is still not very clear from a normative perspective whether this reference would endow those fundamental labour rights with an additional layer of normativity. It is also interesting to observe that the substantive labour rights covered by the FTAs and IFIs are in growing convergence.

Secondly, those transnational labour standards usually go beyond the purview of fundamental labour rights. Typically, these may involve safe working conditions. This is the least politically sensitive and morally uncontested part of labour standards. It is among the first cluster of labour standards received by the IFIs. The World Bank's current standards on occupational health and safety are extensive. They require, among others things, identification of potential hazards, preventive and protective measures, preparedness for and responses to emergencies, and effective remedies for occupational injuries, deaths, disability and disease. Other standards may involve workers' rights related to hours of work, minimum wages, overtime compensation and benefits, ${ }^{49}$ social security, ${ }^{50}$ and the protection of migrant workers. ${ }^{51}$

Thirdly, these transnational labour standards are designed with autonomous mechanisms of enforcement. In the case of FTAs, labour standards are enforceable through cooperation, technical assistance and labour consultation, or even by recourse to dispute settlement procedures or unilateral trade sanctions. In 2014 the United States brought the first labour dispute case against Guatemala, utilizing the dispute settlement procedure under the Dominican Republic-Central AmericaUnited States Free Trade Agreement, yet failed to establish the failure of Guatemala's enforcement of its labour law in a sustained or recurring manner according to the

\footnotetext{
${ }^{48}$ International Labour Office (2016) Third Item on the Agenda - labour-related provisions in trade agreements: recent trends and relevance to the ILO (GB.328/POL/3), Governing Body, 328th Session, Geneva, 27 October-10 November 2016; Agustí-Panareda et al. (2014).

${ }^{49}$ International Labour Office (2016) Third Item on the Agenda - labour-related provisions in trade agreements: recent trends and relevance to the ILO (GB.328/POL/3), Governing Body, 328th Session, Geneva, 27 October-10 November 2016, p. 54.

${ }^{50}$ See EBRD (2008b).

${ }^{51}$ See EIB (2013), p. 70.
} 
final report of the arbitration panel in 2017..$^{52}$ In the case of IFIs, labour standards are enforceable through a variety of means and procedures, including prior plans or commitments of the borrower, a project-specific on-site grievance mechanism, independent labour inspection, or an IFI complaint mechanism. This means that these transnational labour standards are not only independent from the ILO, but also may be more effective than ILO supervisory mechanisms.

In the course of diffusion of labour standards, the ILO has played an indispensable role. It has been not unusual that the ILO gets involved or is consulted in the labour provisions of FTAs. The ILO itself has confirmed that "trade partners have requested the ILO's advice through technical assistance on various questions related to labour standards and practices". ${ }^{33}$ This applies even more so in the case of IFI labour standards. For example, the EBRD actively resorted to ILO expertise when designing its labour standards. In 2006, a thematic meeting on labour issues was hosted by the ILO where EBRD staff met with representatives from trade unions, employers, and ILO experts. ${ }^{54}$ Another prominent example can be found in the formulation of the Environmental and Social Framework of the World Bank. The World Bank has organized three labour expert meetings respectively in Jakarta (2013), London (2015) and Washington (2015). ${ }^{55}$ In all these meetings, ILO representatives were present.

Inter-agency learning is also an important factor accounting for the spread of labour standards in the case of IFIs. The Multilateral Finance Institutions Working Group on the Environment (MFI-WGE) was initiated in the 1990s and serves as a useful platform for senior IFI managers to discuss and coordinate policies towards environmental and social issues. As social issues are increasingly included in safeguards policy, this working group was recently renamed as the Multilateral Finance Institutions Working Group on Environmental and Social Standards (MFI-WGESS). This working group is rather informal but has been instrumental for institutional learning on environmental and social standards. For example, the African Development Bank expressly acknowledged that its earlier drafts of safeguards policies "have been reviewed by the IFC, World Bank, Asian Development Bank and other members of the MFI Working Group on the Environment (MFI-WGE)" ${ }^{56}$ The World Bank also expressly acknowledged that its labour standards are "derived from provisions of other MDBs [multilateral development banks] ${ }^{.57}$

\footnotetext{
${ }^{52}$ Arbitral Panel established pursuant to Chapter 20 of the CAFTA-DR (2017).

${ }^{53}$ International Labour Office (2016) Third Item on the Agenda - labour-related provisions in trade agreements: recent trends and relevance to the ILO (GB.328/POL/3), Governing Body, 328th Session, Geneva, 27 October-10 November 2016.

${ }^{54}$ See EBRD (2006), p. 11.

${ }^{55}$ See World Bank (2013, 2015a, b).

${ }^{56}$ See the statement in African Development Bank Group (2013), Acknowledgements.

${ }^{57}$ World Bank (2014a), p. 11.
} 


\section{In Relation to ILO Standards: The Ambivalence of Transnational Labour Standards}

An interesting aspect of transnational labour standards is their relationship with ILO standards. More specifically, when transnational labour standards give concrete expressions to core labour standards, should reference be to the ILO fundamental labour conventions and the ILO Declaration on Fundamental Principles and Rights at Work of 1998, or should transnational labour standards simply embody the substance of the core labour standards without resorting or referring to specific ILO documents?

The practice has been diverse. Some IFIs tend to make a full reference to the ILO fundamental labour conventions. This is the case for the IFC's Performance Standards of 2006. The IFC expressly acknowledges that its labour standards "have been in part guided by a number of international conventions negotiated through the ILO and the UN". A further reference to all eight ILO fundamental labour conventions was detailed in a footnote. ${ }^{58}$ The same applies more or less to the EBRD's Environmental and Social Policy of 2008, and to the AfDB Group's Integrated Safeguards System of 2013. Some other IFIs with a relevant succinct policy document may avoid explicit reference to the ILO conventions, as in the case of the NIB's Sustainability Guidelines of 2012. Another way of looking at the matter is by examining the portfolios and activities of the IFIs. Those IFIs engaged more, or exclusively, with the private sector are more inclined to refer to the ILO conventions. On the contrary, those engaged more with the public sector are more cautious in referring to the ILO conventions.

It seems that FTAs are more receptive towards referring to the ILO Declaration and fundamental labour rights. Most recent FTAs with labour provisions have made reference to the 1998 Declaration. It has been customary for Canada to refer to the 1998 Declaration in its FTAs with labour provision. Yet, the degree of integration varies under different FTAs, as do the legal effects of the ILO Declaration. ${ }^{59}$ For example, the North American Free Trade Agreement of 2018 makes repeated reference to the 1998 Declaration. ${ }^{60}$ In the EU-Canada Comprehensive Economic and Trade Agreement of 2016, the agreement actually calls upon the states to "make continued and sustained efforts to ratify the fundamental ILO Conventions if they have not yet done so". 61

To refer or not to refer to ILO standards is not just a matter of formality or theoretical interest. Rather, this will largely affect the normative operation of transnational labour standards, as well as their foundational authority. Are transnational labour standards simply to be understood as no more than a transposed expression of established ILO labour standards, or rather, does their authority derive from the

\footnotetext{
${ }^{58}$ IFC (2012), Performance Standard 2 Labor and Working Conditions, para 2.

${ }^{59}$ Agustí-Panareda et al. (2014).

${ }^{60}$ North American Free Trade Agreement, 30 November 2018.

${ }^{61}$ EU-Canada Comprehensive Economic and Trade Agreement, 30 October 2016.
} 
labour provisions themselves and as such constitute a set of labour standards sui generis? And if there should arise differences of opinion on certain labour standards, would the IFIs or trade partners have to resort to the ILO conventions and relevant jurisprudence to search for a correct interpretation, or would the IFIs or trade partners be entitled to develop their own institutional standards and jurisprudence?

When the World Bank drafted its labour standards, a number of Western countries requested the World Bank to link its labour standards to the ILO conventions. ${ }^{62}$ The United States urged the Bank to incorporate reference to the ILO Declaration on the Fundamental Principles and Rights at Work ${ }^{63}$ The ILO also actively lobbied for the inclusion of the ILO conventions. An obvious advantage of reference to the ILO conventions is that the very content of IFI labour standards has a reliable source and solid ground. To borrow the ILO standards could avoid re-opening many debates that were already concluded at the time of drafting ILO conventions. At the end of the day, since IFIs are not specialized in labour protection, it may be desirable to heed the knowledge and expertise of the ILO. Moreover, as the ILO standards are internationally recognized, it may also be conducive to a uniform application of labour standards.

Yet, the proposal to incorporate the ILO conventions in World Bank social policies was viewed with much vigilance among developing countries. The major concern is that this might amount to a de facto imposition of the ILO conventions and bypass ratification procedures. ${ }^{64}$ In other words, the ILO fundamental labour conventions may be enforced through World Bank policies against a borrowing country even if the country has not acceded to all the ILO fundamental conventions. The traditional ILO approach to the promotion of labour standards relies upon voluntary ratification of labour conventions by states. And to ratify, or not to ratify, a treaty is always an essential feature of the sovereign prerogative. However, if the ILO conventions are referred to in the labour standards of the IFIs, then sovereign borrowers are obliged to implement those labour standards in the role of clients irrespective of their non-ratification. World Bank labour standards would be equivalent to a coerced application of the ILO conventions. It is therefore in the consultation phase that China suggested the Bank confine itself to reference to general principles, but not to the ILO conventions. ${ }^{65}$

At the same time, there is another important aspect to the matter. It would not only have normative relevance on the operation of transnational labour standards, but also has strong implications for the relationship between international actors and the ILO. It is in the interest of the ILO to develop a body of ILO-centred labour

\footnotetext{
${ }^{62}$ See for an example, World Bank (2014b).

${ }^{63}$ World Bank (2015c).

${ }^{64}$ For example, the ADB considers the core labour standards as automatically applicable. "Internationally recognized labor standards, when ratified, are also part of the legislative framework of a DMC. With regard to the Core Labor Standards, no explicit ratification is needed for them to be part of the legislative framework of a country." See ADB (2003), p. 15.

${ }^{65}$ World Bank (2015d).
} 
standards at the global level. A reference to the ILO and its work would naturally reinforce the authority of the ILO in labour matters. To a certain extent, a strengthened role for the ILO is also in the interest of the international community in general. The emergence of autonomous labour standards outside the ILO system could possibly divert and compete with the ILO and its standard-setting authority.

Seen in this light, one may gain a better appreciation of the institutional rivalry between the World Bank and the ILO. The World Bank in its Environmental and Social Framework decided against direct reference to any ILO instruments. ${ }^{66}$ In explaining its decision, the World Bank made it very clear that it is exactly the autonomy of labour standards and of the Bank that animates such a political decision:

It is Management's view that the requirement for both World Bank and Borrower to comply with the ES [Environmental and Social] Framework should be self-standing, and should not require reference to external sources to make this judgment. ${ }^{67}$

The ILO was profoundly disappointed at this decision. Immediately after the World Bank published its Environmental and Social Framework, the ILO publicly pronounced its dissatisfaction. It stated that "from the outset the ILO expressed concern with Bank Management's decision to exclude direct references to ILO core labour conventions from the ESF [Environmental and Social Framework]." ${ }^{68}$

The case of the World Bank makes a good example that highlights the autonomous status of transnational labour standards. The legal validity of these labour standards does not depend on the ILO conventions or other normative documents. Nor is the substance of those transnational labour standards defined or constrained by the ILO conventions. Transnational labour standards constitute a set of independent, self-contained labour standards with distinct sources, procedures and mechanisms, in parallel to the traditional concept of international labour law centred on and formulated by the ILO. Although these labour standards do strengthen labour protection at global and transnational levels, they are necessarily associated with the ILO standards. In this sense, even though the substance of transnational labour standards might be identical to those in ILO standards, they are capable of supplementing, or even competing with, ILO standards. They are not at all simply a repetition of existing standards.

The difference between the World Bank and the ILO is not concerned with actual labour standards, but about who is entitled to prescribe labour protection in an increasingly globalized world. While the authority of the ILO is highly acknowledged, the World Bank has refused to concede the ILO a monopolized say on labour standards. Putting it differently, the ILO does not have higher authority than the World Bank in speaking to labour standards. It can be expected that close

\footnotetext{
${ }^{66}$ The attitude of the World Bank towards external institutions has been consistently conservative. A known example is World Bank's explicit rejection of the binding force of the resolution of the United Nations (UN) Security Council acting under the Chapter VII of the UN Charter.

${ }^{67}$ World Bank (2015e).

${ }^{68} \mathrm{ILO}(2016)$.
} 
cooperation between the World Bank and the ILO will increase and grow steadily in the future. Meanwhile, with assistance from the ILO, the World Bank is likely to develop its own expertise and knowledge in labour protection in connection with its own labour policy and project implementation.

\section{Institutional Politics of Labour Standards}

Even though core labour standards receive broad endorsement, their substance and actual enforcement exhibit profound differences in practice. For example, it is noticed that different countries have very different approaches to the workers' right of unionization. There was, and probably still is, hesitation among IFIs to include freedom of association and collective bargaining, which is considered a highly political and sensitive issue in borrowing countries. Even for those rights of a seemingly less political nature, such as the prohibition of child labour, the matter may also be received with divergent attitudes in different cultures.

Freedom of association is probably the most politically sensitive right of workers. For many countries, freedom of association lies at the heart of labour protection. And freedom of association is deeply embedded in the liberal political tradition. Labour protection through institutionalized unionization of labour has functioned in a highly effective manner in countries like Sweden and Finland ${ }^{69}$ Yet in some other countries the right to organize is not purely a matter of labour protection and its exercise is restricted by law or in practice. ${ }^{70}$ This may include prior approval or registration of the formation of trade unions, and other forms of restriction. The difference of positions among states towards the right to organize is also demonstrated by the fact that a number of countries have not ratified the Freedom of Association and Protection of the Right to Organize Convention (No. 87) or the Right to Organize and Collective Bargaining Convention (No. 98). Out of the eight ILO fundamental conventions, these two conventions have received the least number of ratifications. $^{71}$

The initial attitude of IFIs towards freedom of association has also been deeply cautious. The labour rights tackled by IFIs used to have a limited spectrum with a special focus on safe working conditions and prohibition of child or forced labour. An explicit reference to freedom of association was often absent. As observed by

\footnotetext{
${ }^{69}$ See for example Fahlbeck and Mulder (2009), pp. 16-18.

${ }^{70} \mathrm{See}$ the observations of the ILO in its global report on the freedom of association, in ILO (2008), p. 11.

${ }^{71}$ By the end of May 2020, 155 countries had ratified the ILO Convention No. 87. See ILO (n.d.-a). 167 countries have ratified ILO Convention No. 98. See ILO (n.d.-b). These numbers are much lower than other 6 ILO fundamental conventions. In contrast, the Worst Forms of Child Labour Convention (No. 182) has received 186 ratifications so far.
} 
Francis Maupin, the former legal counsel of the ILO, "freedom of association and collective bargaining continue to be regarded as civil rights which [World] Bank activities might facilitate, but it still believes that it is not in its mandate to actively promote them, and even less so where they might interfere with economic performance". ${ }^{72}$ This is partly due to the economic perspective of seeing trade unions negatively as free riders. ${ }^{73}$ Moreover, many developing countries where the IFIs operate hold a conservative position towards freedom of association, and those IFIs engaging with public sectors are barred from interfering in the internal affairs of the borrowing sovereigns. This was still the case when the World Bank proposed its first draft of the Environmental and Social Framework in 2014. In its standard on labour and working conditions, the World Bank refrained from mentioning freedom of association among its objectives, instead adopting a deferential attitude to the borrowing country. It expressly limited its support to freedom of association, that is, only if the national laws of the borrowing country recognize it. ${ }^{74}$

This cautious approach by the World Bank met with fierce criticism from labour NGOs and experts, the ILO and developed countries. ${ }^{75}$ The main arguments are summarized as follows. To start with, all core labour standards are indivisible and as a whole they constitute the floor of protection for workers. There is no reason to segregate freedom of association from other standards. Secondly, freedom of association and collective bargaining are political rights by nature, as indeed are other core labour standards. Freedom of association cannot justifiably be excluded on the grounds of its political nature. Thirdly, the silence of the World Bank might be construed as being permissive of suppressive or retaliatory measures against workers seeking to exercise freedom of association. Fourthly, the obligation to promote core labour standards arises from states' membership in the ILO. As such, neither the World Bank nor the states themselves should refuse to implement freedom of association on the basis of national laws. ${ }^{76}$

The World Bank quickly yielded to this pressure after the first round of consultation. The Bank switched to the opposite position in the second draft of the Environmental and Social Framework and provided unqualified support to freedom of association as part of its labour policy. This radical change of position generated great concern among developing countries. The primary concern was the unqualified nature of the World Bank statement. It is suggested by countries such as China that the exercise of freedom of association and collective bargaining should be in accordance with the national laws of borrowing countries. ${ }^{77}$ Some also suggest that the arrangement concerning freedom of association and collective bargaining should

\footnotetext{
${ }^{72}$ Maupain (2013), p. 78.

${ }^{73}$ It used to be the mainstream opinion of the World Bank, see Murphy (2014), pp. 405 and 417.

${ }^{74}$ World Bank (2014c).

${ }^{75}$ See World Bank (2015f).

${ }^{76}$ ITUC/Global Unions (2014), pp. 2-3.

${ }^{77}$ For the opinions of China, see World Bank (2015g).
} 
be expressed so as not to frustrate project implementation. ${ }^{78}$ In response, the World Bank decided to qualify its wording to "support the principles of freedom of association and collective bargaining of project workers in a manner consistent with national law". ${ }^{79}$ This formula entered the final text of the World Bank's Environmental and Social Policy in 2016. Yet, this formula does not satisfy the ILO and trade unions, who see this as a concession from the internationally accepted standards. ${ }^{80}$

One may further suggest that the challenge for IFIs in terms of incorporating labour standards is not only institutional, but also intellectual and philosophical. The most difficult part is how to integrate labour protection into the mainstream economic theories of IFIs. Typically, an economic perspective treats labour as a factor of production and is usually in favour of flexibility of labour markets and deregulation of social protection.

The controversies surrounding the World Bank publication "Doing Business" provide another illustrative example of embedded neoliberal economic thoughts among IFIs. "Doing Business" is a flagship publication of the World Bank, launched in 2004, aiming to measure the business environment across the world with quantitative indicators. In its early years, the "Employing Workers" indicator largely measured rigidity of hiring and firing workers and their employment conditions. Its underpinning philosophy is that rigid labour regulation leads to unemployment in formal sectors, and ultimately reduction in productivity growth. ${ }^{82}$ Accordingly, the more regulatory and protective a country's labour regulations are, the lower the ranking it receives. ${ }^{83}$ And among the recommended reform measures are introduction of part-time and fixed-term employment contracts, and reduction of the minimum wage for young workers. ${ }^{84}$

This provoked fierce protests from the ILO, trade unions and labour law scholars in general. ${ }^{85}$ The ILO criticized the methodological flaws of the Employing Workers indicator and expressed the concern that the ranking system would "discourage countries from ratifying and abiding by international labour Conventions and Recommendations". ${ }^{86}$ The international trade unions are profoundly concerned with the fundamental bias against labour regulation of the Employing Workers indicator. They condemned in particular the fact that the World Bank, in using the

\footnotetext{
${ }^{78}$ World Bank (2016a), p. 4.

${ }^{79}$ World Bank (2016b), p. 22.

${ }^{80}$ The qualification of "in a manner consistent with national law" was harshly criticized by the ILO for the reason that the formula as such "undercuts the universal principles adhered to by the ILO's 187 member states and jeopardizes the purpose of having such an objective". See ILO (2016).

${ }^{81}$ For the ongoing controversy regarding the publication, see Murphy (2014).

${ }^{82}$ See World Bank (2003), p. 29.

${ }^{83}$ On the politics of knowledge behind the ranking and a case study of the Doing Business Indicators, see Davis et al. (2012).

${ }^{84}$ See World Bank (2003), p. 30.

${ }^{85}$ See Kryvoi (2009), pp. 47-59.

${ }^{86}$ See International Labour Office (2007).
} 
indicators, was eliminating workers' protection. ${ }^{87}$ In response, the World Bank conceded a more balanced approach to labour protection, committed to a better alignment with ILO core labour standards, ${ }^{88}$ and subsequently broadened the spectrum of measurement to include protective elements such as job quality. As of 2011, "Doing Business" has removed labour regulation from the measuring criteria of ranking. Instead, labour regulation is included in the publication only as a referential annex.

Both examples referred to above fully illustrate that labour standards, when transplanted in transnational settings, are constrained and affected by institutional philosophy, culture and norms. Transnational labour standards live different normative lives of their own. They may borrow the ILO standards at their convenience, but are not reluctant to challenge ILO's claim of normative superiority. The politics of labour standards is not only normative and institutional, but also ideological and philosophical.

\section{The Future of the ILO: Leadership in Intellectuality and Normativity}

When established in 1919, the ILO was undoubtedly the only regulatory authority for labour and social life at that time. Entering into the new millennium, the international regulation of labour has turned out to be a crowded field. In addition to the proliferation of normative standards, there is also competition for regulatory competence, and struggle for institutional ideologies. This generates the risk of legal uncertainty, the possibility of forum shopping, as well as inflation of labour rhetoric.

The proliferation of labour standards does not necessarily by itself promise a world of better labour protection. The actual effect of transnational labour standards usually does not offset the adverse impact caused by international economic arrangements. Labour provisions in FTAs could be incorporated to appease anticipated criticism and used to legitimize FTAs, ${ }^{89}$ but may not be able to deliver the aspirations promised on paper. They are even more radically criticised as an instrument of "mutually assured non-compliance". ${ }^{90}$ While adoption of the labour standards by the World Bank was applauded, the limited scope of application among other things also raised doubts as to its practical effectiveness. ${ }^{91}$ Concern was also expressed that the challenge for IFIs in fully incorporating labour standards are

\footnotetext{
${ }^{87}$ ITUC/Global Unions (2007).

${ }^{88}$ See World Bank (2009), pp. 22-23; World Bank (2010), p. 94.

${ }^{89}$ See Santos (2019), pp. 140-174.

${ }^{90}$ See Tham and Ewing (2020).

${ }^{91}$ See, for example, Ebert (2018).
} 
philosophical, constitutional and cultural.$^{92}$ There is indeed a danger of "economisation of core labour rights". ${ }^{93}$

The foremost challenge ahead for the ILO is less about fragmentation of norms, but more about the philosophy of and approach to labour. The difference between a neoliberal approach and a rights-based approach is indeed structural. Another telling example is the attitude of IFIs towards trade unions. The trade unions are considered to be free riders in the view of the World Bank. ${ }^{94}$ The IMF is reported to hold the same opinion. ${ }^{95}$ In essence, trade unions are difficult to analyze in economic terms of efficiency and productivity. In the 2017 evaluation of the IMF on its social policy, some IMF staff members were reported to have felt that the IMF and ILO staffs "did not speak the same language". ${ }^{96}$

To fully integrate labour protection in economic globalization would require a profound change in economic thinking to reconceptualize labour protection as an inherent good. Labour should be approached not purely as a factor of production in economic terms, but also as one of the very foundational values upon which economic activities are based. In other words, trade arrangement and financial institutions have to embed labour protection into their economic work from their foundational philosophy, that is to say, what are the elements of a sound economy and where the boundary of economic activities lies. ${ }^{97}$ This in practice would mean modifying or even rewriting the philosophy of mainstream economic theory, which is a formidable task, if not an impossible one. It would also require the ILO to engage boldly not just in setting labour standards, but in formulating competing economic and social theories against those currently accepted.

At the technical level, the ILO also bears a special responsibility to promote coherence of and genuine respect for labour standards at the global level. First of all, the ILO may wish to further strengthen its normative grip on fundamental labour rights. What the ILO did in its 1998 Declaration was to emphasize the universality of those rights by linking them to the ILO membership of states. Yet this universal approach has the shortcomings of being soft and vague. It places undue emphasis on principles rather than rights, and is also detached from the international labour conventions. ${ }^{98}$ It has been increasingly felt that a reference to the 1998 Declaration does little to clarify the rights as set out in labour provisions. ${ }^{99}$ It may be time for the ILO to review its soft law approach and reconsider the possibility of adopting a

\footnotetext{
${ }^{92}$ See Chen (2018).

${ }^{93}$ See Breining-Kaufmann (2007).

${ }^{94}$ See Murphy (2014), pp. 405 and 417.

${ }^{95}$ See Ebert (2015).

${ }^{96} \mathrm{IMF}$ (2017), p. 30.

${ }^{97}$ For example, the integration of environmental protection in the policy of the World Bank is greatly facilitated by the publication of "Development and the Environment" in 1992, which "presented environmental issues in a language that economists (inside and outside the Bank) could understand". See Wade (1997), pp. 712-713.

${ }^{98}$ See Alston (2004).

${ }^{99}$ See, for examples, Ushakova (2018); also Tham and Ewing (2020).
} 
comprehensive fundamental labour rights convention. This convention could be open to states and international organizations alike for accession.

Secondly, at the inter-agency level the ILO might also be more actively engaged in the enforcement of transnational labour standards. Some trade agreements actually conceive such a role for the ILO. For example, the EU-Canada Comprehensive Economic and Trade Agreement stipulates that, when the dispute settlement procedure is resorted to for settling issues related to fundamental labour rights, "the Panel of Experts should seek information from the ILO, including any pertinent available interpretative guidance, findings or decisions adopted by the ILO". ${ }^{100}$ This is a selfconscious effort to promote greater legal certainty in the field. It is also recognized in the North American Free Trade Agreement of 2008 that in the dialogue procedure the parties may request the ILO for independent verification of compliance. ${ }^{101}$ Proliferation of labour standards does not necessarily lead to normative fragmentation and institutional confrontation. ${ }^{102}$ International actors are generally cautious to not overrule one another's standards too lightly.

Thirdly, the existing supervisory mechanism of the ILO, which evaluates the performance of member states under ratified ILO conventions, could also provide a useful reference as to the observance of ILO standards by states under other commitments. The Committee of Experts on the Application of Conventions and Recommendations may also "serve as a source of guidance" when it comes to the interpretation of labour provisions. ${ }^{103}$ It is acknowledged in FTAs that trade partners "may establish cooperative arrangements with the ILO and other competent international or regional organisations to draw on their expertise and resources". ${ }^{104}$

Proliferation of labour standards has brought many challenges to the door of the ILO. The ILO should endeavour to reinstate itself as a central institution for economic and social theories as well as for labour standards. Its intellectual capability is as essential as its normative mandate. It is important for the ILO to perform a legal-diplomatic role in promoting convergence of normative understandings about labour, economy and society among different institutions. In doing so, stressing the social dimension of globalization would, one may hope, lead to the revitalization of not only the ILO but workers at large in the economic and political life of the world.

\footnotetext{
${ }^{100}$ EU-Canada Comprehensive Economic and Trade Agreement, 30 October 2016.

${ }^{101}$ North American Free Trade Agreement, 30 November 2018.

${ }^{102}$ For example, in the US-Guatemala labour arbitration, the arbitration panel expressly refers to the ILO 1998 Declaration to ascertain the meaning of right to strike. See Arbitral Panel established pursuant to Chapter 20 of the CAFTA-DR (2017).

${ }^{103}$ Agustí-Panareda et al. (2014).

${ }^{104}$ See for example, EU-Canada Comprehensive Economic and Trade Agreement, 30 October 2016.
} 


\section{References}

ADB (2003) Social protection strategy 2001. Available at: https://www.adb.org/sites/default/files/ institutional-document/32100/social-protection.pdf. Accessed 6 May 2018

AFL-CIO (1998) Executive Council statement on Asian financial crisis (29 January 1998). Available at: https://aflcio.org/about/leadership/statements/asian-financial-crisis. Accessed 6 May 2020

AFL-CIO (2000) Executive Council statement on equitable, democratic, sustainable development (18 February 2000). Available at: https://aflcio.org/about/leadership/statements/equitable-democratic-sustainable-development. Accessed 6 May 2020

African Development Bank Group (2013) Integrated safeguards system: policy statement and operational safeguards. Available at: https://www.afdb.org/fileadmin/uploads/afdb/Documents/ Policy-Documents/December_2013_-_AfDB\%E2\%80\%99S_Integrated_Safeguards_ System___Policy_Statement_and_Operational_Safeguards.pdf. Accessed 6 May 2020

Agustí-Panareda J, Ebert FC, LeClercq D (2014) Labour provisions in free trade agreements: fostering their consistency with the ILO standards system. International Labour Office, Geneva

AIIB (2016) Environmental and social framework (February 2016). Available at: https://www. aiib.org/en/policies-strategies/_download/environment-framework/20160226043633542.pdf. Accessed 6 May 2020

Alston P (2004) Core labour standards and the transformation of the international labour rights regime. Eur J Int Law 15(3):457-522

Arbitral Panel established pursuant to Chapter 20 of the CAFTA-DR (2017) Final report of the Panel in the matter of Guatemala - issues relating to the obligations under Article 16.2.1(a) of the CAFTA-DR (14 June 2017). Available at: https://legacy.trade.gov/industry/tas/Guatemala\%20 $\% 20 \%$ E2\% $80 \% 93 \% 20$ Obligations $\% 20$ Under\%20Article $\% 2016-2-1$ (a)\%20of $\% 20$ the $\% 20$ CAFTA-DR\%20\%20June\%2014\%202017.pdf. Accessed 6 May 2020

Blackett A, Trebilcock A (eds) (2015) Research handbook on transnational labour law. Edward Elgar, Cheltenham

Bolle MJ (2016) Overview of labor enforcement issues in free trade agreements. Available at: https://fas.org/sgp/crs/misc/RS22823.pdf. Accessed 6 May 2020

Breining-Kaufmann C (2007) Globalisation and labour rights: the conflict between core labour rights and international economic law. Hart, Oxford

BSTDB (2014) Environmental and social policy (1 January 2014). Available at: https://www. bstdb.org/Environmental_Policy_Feb2016.pdf. Accessed 6 May 2020

Chen Y (2018) The making of global public authorities: the role of IFIs in setting international labor standards. In: Quayle P, Gao X (eds) AIIB yearbook of international law vol 1: good governance and modern international financial institutions. Brill Nijhoff, Leiden

Compa L (1995) Going multilateral: the evolution of U.S. hemispheric labor rights policy under GSP and NAFTA. Conn J Int Law 10(2):337-364

Craig JDR, Lynk SM (eds) (2006) Globalization and the future of labour law. Cambridge University Press, Cambridge

Davis KE, Kingsbury B, Merry SE (2012) Indicators as a technology of global governance. Law \& Soc Rev 46(1):71-104

de Wet E (2010) Governance through promotion and persuasion: the 1998 ILO declaration on fundamental principles and rights at work. In: von Bogdandy A, Wolfrum R, von Bernstorff J, Dann P, Goldmann M (eds) The exercise of public authority by international institutions. Springer, Heidelberg

Ebert FC (2015) International financial institutions' approaches to labour law: the case of the International Monetary Fund. In: Blackett A, Trebilcock A (eds) Research handbook on transnational labour law. Edward Elgar, Cheltenham

Ebert FC (2018) Labour standards and the World Bank. Analysing the potential of safeguard policies for protecting workers. In: Gött $\mathrm{H}$ (ed) Labour standards in international economic law. Springer, Cham 
EBRD (2003) Environmental policy 2003. Available at: http://www.ebrd.com/downloads/research/ policies/policy.pdf. Accessed 6 May 2020

EBRD (2006) Sustainability report 2006. Available at: https://www.ebrd.com/publications/annualreport-2006.pdf. Accessed 6 May 2020

EBRD (2008a) Sustainability report 2008. Available at: https://www.ebrd.com/downloads/ research/sustain/sr08e.pdf. Accessed 6 May 2020

EBRD (2008b) Environmental and social policy (12 November 2008). Available at: http://ebrd. com/downloads/research/policies/2008policy.pdf. Accessed 6 May 2020

EIB (2013) Environmental and social handbook. Available at: http://www.eib.org/attachments/ strategies environmental_and_social_practices_handbook_en.pdf. Accessed 6 May 2020

Fahlbeck R, Mulder BJ (2009) Labour and employment law in Sweden. Juristförlaget, Lund

GATT (1987) Relationship of internationally-recognized worker rights to international trade: communication from the United States, L/6196 (3 July 1987)

Hepple B (2005) Labour laws and global trade. Hart, Oxford

IFC (2006) Performance standards on social \& environmental sustainability (30 April 2006). Available at: https://www.ifc.org/wps/wcm/connect/3f3419f4-6043-4984a42a-36f3cfaf38fd/IFC\%2BPerformance\%2BStandards.pdf?MOD=AJPERES\&CVID=jkC. Eka\&id=1322803957411. Accessed 6 May 2020

IFC (2012) Performance standards on environmental and social sustainability (1 January 2012). Available at: https://www.ifc.org/wps/wcm/connect/c02c2e86-e6cd-4b55-95a2b3395d204279/IFC_Performance_Standards.pdf?MOD=AJPERES\&CVID=kTjHBzk. Accessed 6 May 2020

ILO (n.d.-a) Ratifications of C087 - Freedom of Association and Protection of the Right to Organise Convention, 1948 (No. 87). Availabe at: http://ilo.org/dyn/normlex/en/f?p=NORML EXPUB:11300:0::NO:11300:P11300_INSTRUMENT_ID:312232:NO. Accessed 6 May 2020

ILO (n.d.-b) Ratifications of C098 - Right to Organise and Collective Bargaining Convention, 1949 (No. 98). Available at: http://ilo.org/dyn/normlex/en/f?p=NORMLEXPUB:11300:0::N O:11300:P11300_INSTRUMENT_ID:312243:NO. Accessed 6 May 2020

ILO (1994) Defending values, promoting change: social justice in a global economy: An ILO agenda: Report of the Director-General. International Labour Office, Geneva

ILO (1997) ILO, standard setting and globalization: Report of the Director-General, International Labour Conference, 85th Session, Geneva, 1997

ILO (1998) Report of the Committee on the Declaration of Principles, International Labour Conference, Record of Proceedings, 86th Session, Geneva, 1998

ILO (2008) Freedom of association in practice: lessons learned, global report under the follow-up to the ILO Declaration on Fundamental Principles and Rights at Work. International Labour Office, Geneva

ILO (2016) Statement on the World Bank environmental and social policy (8 August 2016). Available at: http://www.ilo.org/global/about-the-ilo/newsroom/statements-and-speeches/ WCMS_508328/lang\%2D\%2Den/index.htm. Accessed 6 May 2020

ILO (2017) Handbook on assessment of labour provisions in trade and investment arrangements. International Labour Office, Geneva

IMF (2017) The IMF and social protection: 2017 evaluation report. Available at: https://ieo.imf. org/en/our-work/Evaluations/Completed/2017-0724-the-imf-and-social-protection. Accessed 6 May 2020

International Labour Office (2007) Fourth item on the agenda - the United Nations and reform: developments in the multilateral system, World Bank Doing Business report: the employing workers indicator (GB.300/4/1), Governing Body, 300th Session, Geneva, November 2007

ITUC/Global Unions (2007) The IFIs' use of Doing Business to eliminate workers' protection: analysis of Doing Business 2008 and new country evidence. Available at: https://www.ituc-csi. org/IMG/pdf/doing_business.pdf. Accessed 6 May 2020

ITUC/Global Unions (2014) Major weaknesses in World Bank's draft labour standards safeguard (22 July 2014). Available at: https://consultations.worldbank.org/sites/default/files/consulta- 
tion-template/review-and-update-world-bank-safeguard-policies/submissions/ess2-wb_ituccritique_0714.pdf. Accessed 6 May 2020

Kryvoi Y (2009) The World Bank and the ILO: two visions of employment regulation. In: Blanpain R, Grant C (eds) Fixed-term employment contracts: a comparative study. Vanden Broele, Bruges

La Hovary C (2018) The ILO's mandate and capacity: creating, proliferating and supervising labour standards for a globalized economy. In: Gött H (ed) Labour standards in international economic law. Springer, Cham

Maupain F (2005) Revitalization not retreat: the real potential of the 1998 ILO declaration for the universal protection of workers' rights. Eur J Int Law 16(3): 439-465.

Maupain F (2013) The future of the international labour organization in the global economy. Hart, Oxford

Murphy H (2014) The World Bank and core labour standards: between flexibility and regulation. Rev Int Polit Econ 21(2):399-431

NDB (2016) Environmental and social framework (11 March 2016). Available at: https://www. $\mathrm{ndb}$.int/wp-content/themes/ndb/pdf/ndb-environment-social-framework-20160330.pdf. Accessed 6 May 2020

NIB (2012) Sustainability policies and guidelines (21 March 2012). Available at: https://www.nib. int/filebank/56-Sustainability_Policy_Guidelines-2012.pdf. Accessed 6 May 2020

OECD (1996) Trade, employment, and labour standards: a study of core workers' rights and international trade. OECD Publications Service, Paris

Santos A (2019) The lessons of TPP and the future of labor chapters in trade agreements. In: Kingsbury B, Malone D, Mertenskötter P, Stewart RB, Streinz T, Sunami A (eds) Megaregulation contested: global economic ordering after TPP. Oxford University Press, Oxford

Standing G (2008) The ILO: an agency for globalization? Development and Change 39(3):355-384

Swepston L (1994) The future of ILO standards. Monthly Labour Rev 117(9):16-23

Tapiola K (2018) The teeth of the ILO - the impact of the 1998 ILO Declaration on Fundamentals Principles and Rights at Work. International Labour Office, Geneva

Tham JC, Ewing KD (2020) Labour provisions in trade agreements: neoliberal regulation at work? Int Org Law Rev 17(1):153-177

UN (1995) Report of the World Summit for social development, Copenhagen, 1995

United States Senate (1957) Contribution to the international labour organization: hearings before the committee on foreign relation. United States Government Printing Office, Washington

United States Senate (1995) Reorganization and revitalization of America's Foreign Affairs Institutions: hearings and markups before the committee on foreign relations and the subcommittee on international operations of the committee on foreign relations. United States Government Printing Office, Washington

Ushakova T (2018) The Trans-Pacific partnership labour chapter: a new paradigm of the social clause? In: Gil y Gil JL (ed) Trade and labour standards: new trends and challenges. Cambridge Scholars Publishing, Newcastle upon Tyne

Wade R (1997) Greening the Bank: the struggle over the environment, 1970-1995. In: Kapur D, Lewis JP, Webb R (eds) The World Bank: its first half century, vol 2: perspectives. Brookings Institution Press, Washington

World Bank (2003) Doing business in 2004: understanding regulation. Available at: https:// www.doingbusiness.org/content/dam/doingBusiness/media/Annual-Reports/English/DB04FullReport.pdf. Accessed 6 May 2020

World Bank (2009) Doing business 2010: reforming through difficult times. Available at: https:// www.doingbusiness.org/content/dam/doingBusiness/media/Annual-Reports/English/DB10FullReport.pdf. Accessed 6 May 2020

World Bank (2010) Doing business 2011: making a difference for entrepreneurs. Available at: https:// www.doingbusiness.org/content/dam/doingBusiness/media/Annual-Reports/English/ DB11-FullReport.pdf. Accessed 6 May 2020.

World Bank (2013) World Bank's safeguard policies review and update - expert focus group on the emerging area labor and occupational health and safety (23 March 2013). Available at: https:// 
consultations.worldbank.org/sites/default/files/meetings/Safeguards_Focus_Group_Labor_ Indonesia_Summary_Final.pdf. Accessed 6 May 2020

World Bank (2014a) World Bank's safeguard policies review and update, proposed environmental and social framework: Background paper (2 September 2014)

World Bank (2014b) Review and update of the world bank's environmental and social safeguard policies, Phase 2 - Feedback summary: consultation with government officials from Belgium and the Netherlands (10 November 2014). Available at: https://consultations.worldbank.org/ sites/default/files/consultation-template/review-and-update-world-bank-safeguard-policies/en/ meetings/safeguard_review_phase_2_consultations_2014_-_feedback_summary_brussels_ government_and_multilaterals_meeting_november_10.pdf. Accessed 6 May 2020

World Bank (2014c) Environmental and social framework: setting standards for sustainable development - First draft for consultation (30 July 2014). Available at: http://documents.worldbank. org/curated/en/311951468331802393/pdf/898130BR0CODE200Box385287B00PUBLIC0. pdf. Accessed 6 May 2020

World Bank (2015a) World Bank's safeguard policies review and update - labour expert group (21 January 2015). Available at: https://consultations.worldbank.org/sites/default/files/consultation-template/review-and-update-world-bank-safeguard-policies/en/meetings/safeguards_london_focus_group_meeting_jan_21.pdf. Accessed 6 May 2020

World Bank (2015b) Meeting of labour experts on the second draft of the World Bank's environmental and social standard 2: labour and working conditions (ESS 2) (18 September 2015). Available at: https://consultations.worldbank.org/sites/default/files/consultation-template/ review-and-update-world-bank-safeguard-policies/en/meetings/ess2_meeting_report_0915. pdf. Accessed 6 May 2020

World Bank (2015c) United States comments on World Bank Safeguards review - Phase 2 (26 March 2015). Available at: https://consultations.worldbank.org/sites/default/files/consultationtemplate/review-and-update-world-bank-safeguard-policies/submissions/2015-3-26_usg_ comments_on_draft_wb_esf_final.pdf. Accessed 6 May 2020

World Bank (2015d) Review and update of the World Bank's environmental and social safeguard policies, Phase 3, Feedback summary: Consultation with Chinese governmental officials (27 October 2015). Available at: https://consultations.worldbank.org/sites/default/files/ consultation-template/review-and-update-world-bank-safeguard-policies/en/meetings/final_ feedback_summary_for_phase_3_consultation_with_chinese_central_government_and_institutions_in_beijing_october_27.pdf. Accessed 6 May 2020

World Bank (2015e) Review and update of the World Bank's safeguard policies environmental and social framework: Environmental and social framework (Proposed second draft), Summary of phase 2 Consultations and Bank management responses (31 July 2014-1 March 2015)

World Bank (2015f) Safeguard policies' review consultations: Nordic Baltic position as of February 23, 2015. Available at: https://consultations.worldbank.org/sites/default/files/consultation-template/review-and-update-world-bank-safeguard-policies/submissions/nordic_baltic_comments_of_27_feb_2015.pdf. Accessed 6 May 2020

World Bank (2015g) Review and update of the World Bank's environmental and social safeguard policies, Phase 3, Feedback summary: consultation with Chinese provincial governments and implementing agencies (29 October 2015). Available at: https://consultations.worldbank.org/ sites/default/files/consultation-template/review-and-update-world-bank-safeguard-policies/en/ meetings/final_feedback_summary_for_phase_3_consultation_with_chinese_provincial_governments_and_pmos_in_yunnan_october_29.pdf. Accessed 6 May 2020

World Bank (2016a) Comments/observations of the Government of Bangladesh on the World Bank's environmental and social safeguard framework and other related documents (6 January 2016). Available at: https://consultations.worldbank.org/sites/default/files/consultation-template/review-and-update-world-bank-safeguard-policies/submissions/comments_from_govt_ of_bangladesh_on_essf-01_12_15.pdf. Accessed 6 May 2020

World Bank (2016b) Review and update of the World Bank's safeguard policies environmental and social framework: Environmental and social framework (Proposed third draft), Summary 
of phase 3 Consultations and Bank management responses (4 August 2015-15 March 2016). Available at: http://documents.worldbank.org/curated/en/748451469107442841/pdf/107175BR-R2016-0145-IDA-R2016-0198-Box396279B-PUBLIC.pdf. Accessed 6 May 2020

Yifeng Chen is an Associate Professor at the Peking University Law School. Before joining Peking University, He was a post-doctoral researcher at the University of Helsinki from 2010-2013 and continues to serve as a docent in international law at the University of Helsinki. He worked as a senior research fellow on the Academy of Finland research project "Implementation of ILO core labour standards in China: legal architecture and cultural logic" (2012-2015). He has worked extensively on history of labour and social laws in Republican China and ILO core labour rights. His fields of interest include history and theory of international law, international organizations, international and comparative labour law.

Open Access This chapter is licensed under the terms of the Creative Commons Attribution 4.0 International License (http://creativecommons.org/licenses/by/4.0/), which permits use, sharing, adaptation, distribution and reproduction in any medium or format, as long as you give appropriate credit to the original author(s) and the source, provide a link to the Creative Commons licence and indicate if changes were made.

The images or other third party material in this chapter are included in the chapter's Creative Commons licence, unless indicated otherwise in a credit line to the material. If material is not included in the chapter's Creative Commons licence and your intended use is not permitted by statutory regulation or exceeds the permitted use, you will need to obtain permission directly from the copyright holder.

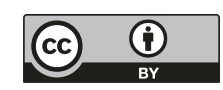

